\title{
Perspectives of refuse-derived fuel in Romania after entrance into the $\mathrm{EU}$
}

\author{
E. C. $\operatorname{Rada}^{1}$, M. Ragazzi ${ }^{1}$ \& I. A. Istrate ${ }^{2}$ \\ ${ }^{1}$ University of Trento, Italy \\ ${ }^{2}$ Politehnica University of Bucharest, Romania
}

\begin{abstract}
On 1 January 2007, Romania entered the European Union. For that reason Romania must comply with all the EU directives in the field of the management of the environment. In 2007, in Romania, Municipal Solid Waste (MSW) was generally landfilled without pre-treatment and energy valorization absent. Some initiatives are in progress but landfilling is still dominant. The entrance in the EU gave an important push to the industrial sectors, increasing the demand of fuels. In this frame an important option regards the use of Solid Recovered Fuel (SRF) as industrial fuel substitute. In Romania, SRF could be generated from MSW using the bio-drying process with post-separation of inert fractions as the percentage of organic fraction in the residual MSW is significant. Today in Romania bio-drying plants for residual municipal waste (RMSW) are under discussion but not yet implemented. The present paper deals with the potential use of SRF in Romania. Some aspects of local and global environmental impact related to a partial substitution of conventional fuels with SRF for industrial uses are discussed too. Some considerations are also based on the assessment of the Romanian SRF characteristics that could be potentially generated. The scenarios that are discussed concern the use of SRF obtainable taking into account also the development of the Romanian MSW composition and the effects of the selective collection evolution. Keywords: bio-drying, cement factory, LHV, Romania, RMSW, SRF.
\end{abstract}

\section{Introduction}

On 1 January 2007, Romania became one of the European Union (EU) members. According to the European Association Agreement, the Romanian development policies must be guided by the principle of sustainable development, taking full account of environmental considerations [1]. 
Romania started to implement the EU principles on waste management before entering in the EU. In 2004, the first plan for waste management for the years 2003-2013 was issued through the national regulation 1470/2004, taking into account the national environmental protection and the sustainable development. In the first instance, waste prevention was indicated, in the second, recycling and energy generation and only in the last one, disposal of waste with no recovery of either materials and/or energy. In 2004, through the regulation 170/2004, the rubber management was imposed and in 2005 the pathway for the adoption of the directive 2000/76/EU on the incineration and co-incineration of waste was completed through regulation 268/2005.

Between 2005 and 2006, the regional waste management plans were developed followed by the county waste management plans in 2007-2009 and by feasibility waste integrated management studies to be financed through "Sectoral Operational Program Environment - SOP ENV 2007-2013". The SOP ENV helps Romania to achieve the EU objectives regarding the protection and improvement of environment quality and to develop basic infrastructure to European standards.

The last regulation issued in Romania, n. 870/2013, regarding the waste management for the period 2014-2020, imposes the up-date of the national waste management plans with the aim to reduce conventional resource consumption and to apply strictly the waste hierarchy. Until 2015 Romania has to develop 30 integrated systems for the waste management at regional and county level. Romania has already obtained a transition period until 2017 for the waste landfilling through the regulation 349/2005 and until 2015 for the import, export and waste transport through regulation 259/93. In the regulation $870 / 2013$ it was indicated that Romania could replace most of the thermal energy produced by conventional plants with the one from waste thermal treatment plants that could treat about $15 \%-20 \%$ of generated waste. In this way the request from the EU legislation 2009/28/EC regarding the use of renewable energy and the ones from the Revised Waste Framework Directive regarding the valorisation of household waste, as a percentage of the total household waste equal to $50 \%$ by 2020 , could be complied.

The mechanical biological treatments (MBT) represent the most used options for the production of "fuel" starting from municipal solid waste (MSW). To this concern a one stream option of MBT could be preferred to a two stream option of MBT as the first one could put to zero the need of landfill volumes [2]. A typical one-stream option is based on the bio-drying process [3-5]. The final material from these processes, named generally solid recovered fuel (SRF), after or without a refining stage (depending on the input materials) can be sent to different thermal plants for energy recovery in concordance with the UNI norms [6-10].

Since 2006, a part of the Romanian industry has begun to support and apply an environment policy putting on the first place the reduction of atmospheric pollution, the ecological products production and the co-combustion of waste for saving natural resources. An important step that the Romanian industrial sector made was the one of a good partnership with the waste sector. The first kinds of waste authorized to be used in the industrial sector as alternative fuel are exhaust oil, sludge, used tires, refuses of the wood sector, paper and also some waste from 
the chemical industry. Generally the use of these fuels is limited to the cement sector. Good examples were given by the Romanian cement factories as:

- Carpatcement Holding cement factory modified its production process in 2004 in order to use also alternative fuels as rubber, plastic, textiles, paper and cardboard, wood, etc. [11];

- Holcim cement factory, has obtained the ISO 14001 certification before the aderation of the Romania to the EU, and today uses about 100 types of waste in its production processes [12];

- Lafarge cement factory implemented different standards for waste use in its plant and also developed a new company, ECOGEST, for the waste valorization [13].

Selective collection (SC) in Romania has a very low efficiency, and for that reason the residual MSW (RMSW) has a high organic fraction content: about $50 \%$ in urban areas $[14,15]$ because of the very low food waste selective collection. For this reason the bio-drying process could be developed successfully as demonstrated by different literature researches [5, 16-20]. After a refining stage SRF can be sent to coal fired power stations or to cement kilns for partially substituting coal and pet-coke [7, 8].

The SRF valorisation can be viewed for Romania as a strategic component of an integrated waste management policy because in this way the quantity of the biodegradable materials that could arrive in a landfill can be reduced as requested from the Landfill Directive from 1999/31/EC, the produced energy can be from renewable sources (the biodegradable part of SRF is considered as biomass) and lastly but most importantly, natural resources use can be decreased.

In this paper an option is presented and discussed for using the Romanian SRF that could be obtained from the RMSW bio-drying.

\section{RMSW bio-drying and SRF}

The situation of Romanian MSW from 2006 to 2011 is presented in fig. 1. Also today a part of the produced MSW is still uncollected (about 10\%) [21]. The collected waste in 2011 was disposed of in 31 sanitary landfills and in 106 not controlled ones ( 75 of these were closed in 2012 and the remaining will be closed until 2017). During the closing of the old uncontrolled landfills, some transfer and sorting stations were constructed: 70 are operating since 2012 [21].

Thanks to the Phare CES 2004 Programme and integrated waste management projects at county level (financed by ISPA or SOP Environment) in 2012, 70 platforms operated for composting biodegradable MSW and about 50 plants and composting platforms were in various stages of implementation and regulation in terms of environmental protection [21]. However all these plants treat only $10 \%$ of the produced biodegradable waste. For this reason, the bio-drying treatment with SRF production and its energy valorisation seems to be the most viable solution for the Romanian MSW [18, 19, 22]. 


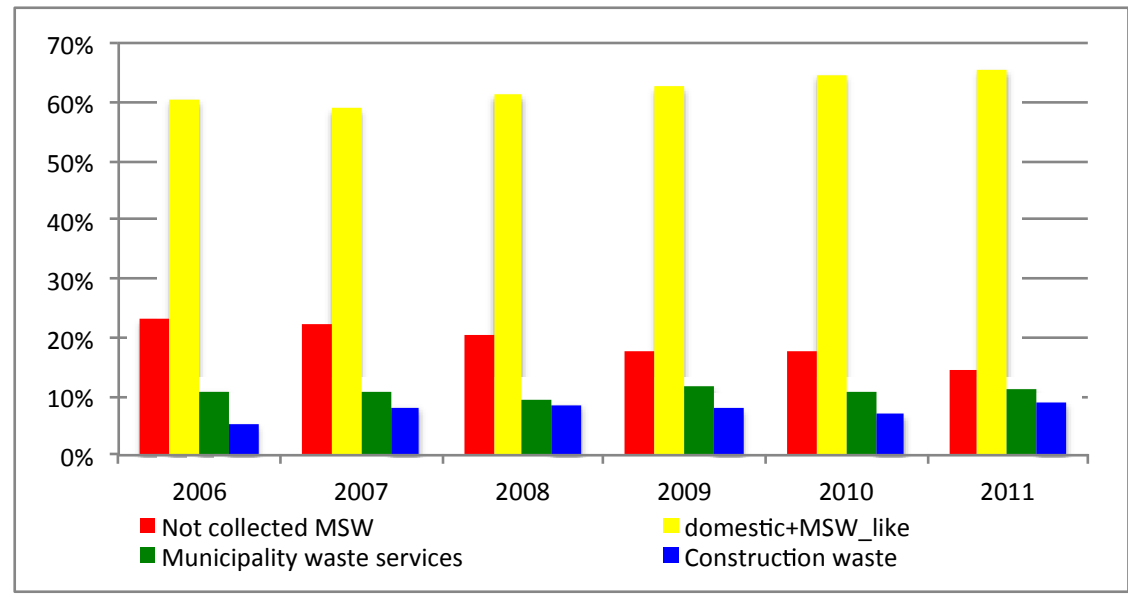

Figure 1: MSW distribution in Romania in 2011.

Romanian RMSW has generally high organic fraction content (about 50\%). Fluctuations can depend on selective collection, but this sector is not yet developed to levels that can significantly affect the RMSW composition as in other EU countries [23-25]. In order to study the viability of bio-drying for generating SRF for Romanian RMSW, this process was applied at pilot scale [1, 3, 5, 18, 19].

The composition used as reference for the Romanian RMSW was calculated starting from the Romanian MSW composition that is shown in fig. 2. The RMSW (biodegradable waste of about 51\%) was calculated also taking into account the efficiency of the transfer and sorting as well as composting stations.

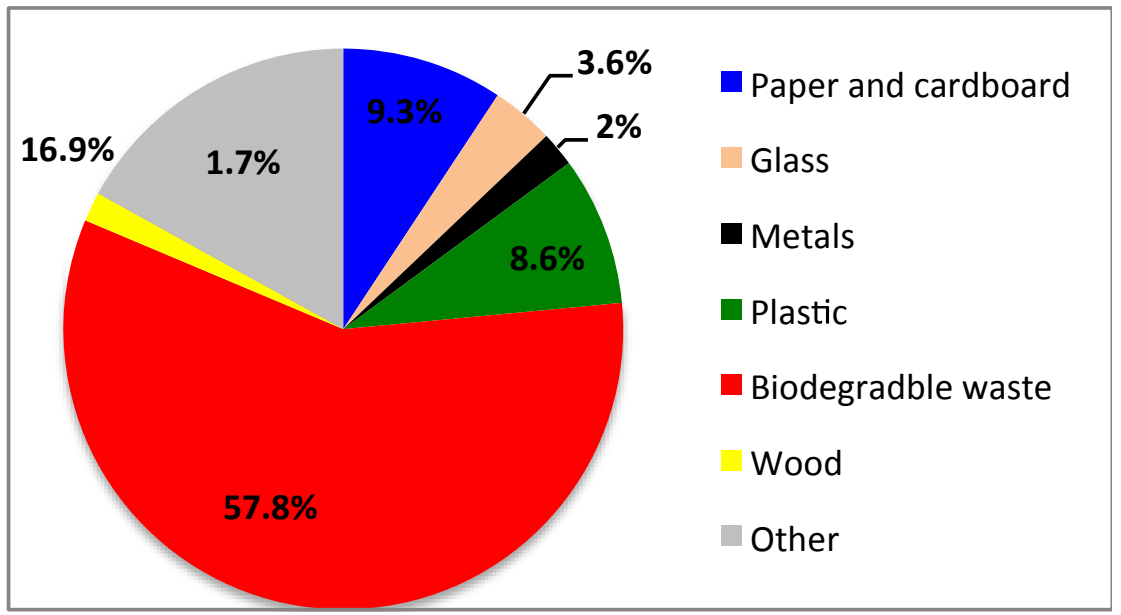

Figure 2: Romanian MSW reference composition. 
The lower heating value (LHV) dynamics of the present Romanian RMSW, bio-dried material (BD) and SRF during the bio-drying treatment are reported in fig. 3 [10]. It must be underlined that the LHV increase of bio-dried material and of SRF after two weeks is respectively around $24 \%$ and $40 \%$. This is not an energy increase because it must be taken into account that the available mass of fuel is lower after the process. The process allows "concentrating" the initial energy with a contemporary consumption of electrical energy. Generally the energy available at the end of the process is about $3 \%$ lower than the initial one $[5,10]$, apart from the electricity needs that change depending on the adopted technology. The SRF was assessed from the material after the bio-drying process taking out the glass, metals and inert fractions.

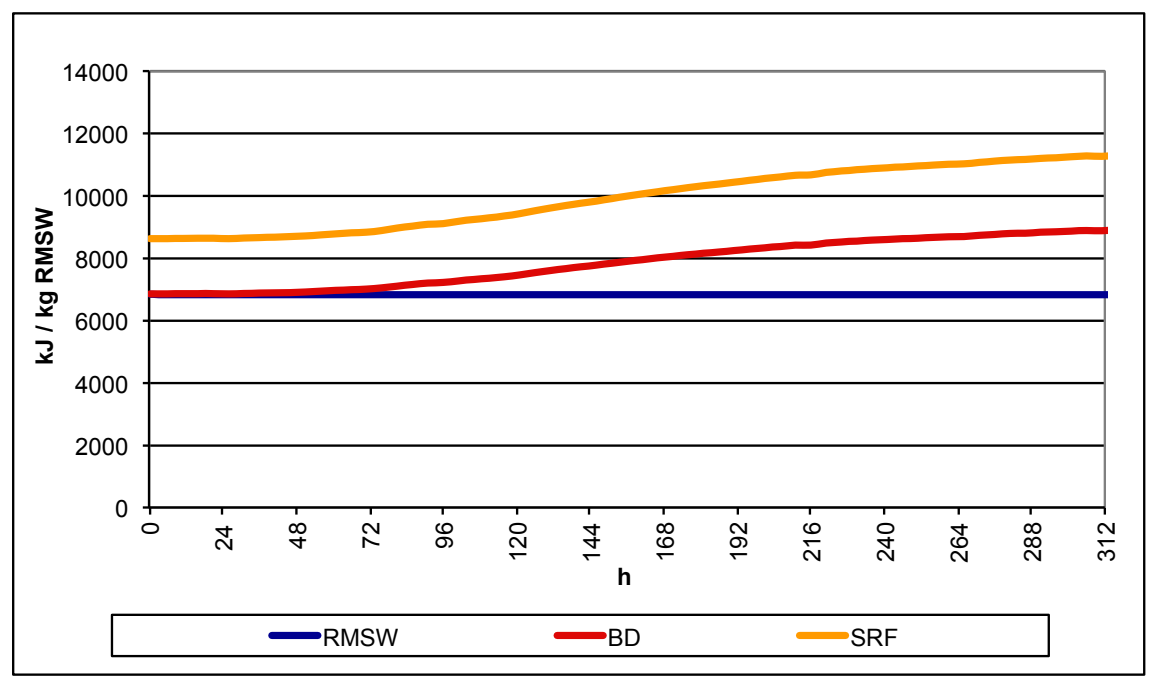

Figure 3: LHV dynamics during the bio-drying process.

The implementation of the principle of waste management and selective collection will change the characteristics of the Romanian MSW and RMSW [24]. Anyway, in spite of the aim to avoid an increase of MSW generation, it must be taken into account that the future per-capita production of MSW is expected to increase. In the future scenario, the quantity of materials with high LHV are expected to decrease in the RMSW thanks to the SC of paper, cardboard a packaging waste. If the Take-Back-Programs (TBP) will be also implemented, the residues from the recycling of these fractions with high LHV will be returned to the RMSW [26]. Also the percentage of biodegradable materials and glass are expected to decrease significantly from RMSW thanks to the SC. Taking into account these indications, the future RMSW composition was hypothesized and its LHV was calculated, resulting to about $10 \mathrm{MJ} / \mathrm{kg}_{\mathrm{RMSW}}$. The presence of inert in RMSW will depend on the correct management of residues from demolition/construction: they are special waste but often a part of them is disposed 
of as MSW. If no attention will be put to this aspect, the percentage of inert in RMSW is expected to increase.

Moreover, it must be underlined for the future Romanian RMSW could be assumed as a SRF-like thanks to its LHV, which is similar with the one producible from the current RMSW (about $11 \mathrm{MJ} / \mathrm{kg}_{\mathrm{SRF}}$ ). This aspect was recently discussed in the literature [26] but more studies must be carried out in order to comply also with the respirometric and chlorine and mercury values to be imposed for a correct management [8]. In practice, RMSW bio-drying could be a viable solution for the years of transition towards an optimized MSW management (contributing in the short period to the compliance of the EU Directives regarding the landfilling minimization and the use of renewable sources of energy), but in the long period its adoption could be no longer necessary.

\section{Potential of SRF use}

The SRF can be used in different thermal plants as indicated in the UNI norms $[7,8]$. In table 1 , the LHV of different conventional and unconventional fuels that can be used in cement factories are reported. The use of these materials in cement factories as a substitute of coal must be in concordance with the environmental limits for the cement factory process air and also must not increase the percentage of the pollutants in the final products of the cement factory. In EU, mainly in Germany and Austria, the substitution came to overcome the $50 \%$ of the traditional fuel. However in these situations very important changes were made to the process air treatment of the plants with an economic investment [10, 27-29].

Table 1: Calorific value of different fuels and fuel-like products.

\begin{tabular}{|l|c|}
\hline Fuels and fuel-like products & Calorific value $[\mathrm{MJ} / \mathrm{kg}]$ \\
\hline Wood & about 16 \\
\hline Paper and cardboard & $3-6$ \\
\hline Textiles & $>40$ \\
\hline Plastic & $17-40$ \\
\hline SRF & $5-22$ \\
\hline Rubber & about 26 \\
\hline Industrial sludge & $8-14$ \\
\hline Urban sludge & $12-16$ \\
\hline Fat animal waste & $14-32$ \\
\hline Coal & $20-30$ \\
\hline Agricultural waste & $12-16$ \\
\hline Oil & $25-36$ \\
\hline
\end{tabular}

Generally, for one $\mathrm{kg}$ of concrete, it is necessary to provide about $3,300 \mathrm{~kJ} / \mathrm{kg}$ of thermal energy in the clinker kiln and between 90 and $150 \mathrm{kWh} / \mathrm{t}_{\text {concrete }}$ of electric energy [11-13]. For this reason, the use of SRF became in recent years the most attractive solution. Another important aspect connected to the SRF use in the cement factory regards the reduction of greenhouse gas effects as $\mathrm{CO}_{2}$ and $\mathrm{SO}_{2}$ 
thanks to the high temperature in the co-incineration techniques (about $1500^{\circ} \mathrm{C}$ ). Concerning $\mathrm{NO}$ and $\mathrm{NO}_{2}$ (that is, $\mathrm{NOx}$ ) the high temperature of co-combustion in cement works causes an increase in their emissions. Taking into account that the basic off-gas treatment line of such a plant is simpler than the one of a modern incinerator, the emission factor of $\mathrm{NO}_{\mathrm{x}}$ could be worsen. In order to avoid problems with the local air quality, innovative approaches are under discussion, thanks to the availability of $\mathrm{NO}_{2}$ sensors that can be placed in strategic sites of the territory to act as sentinels [30]. However, these additional costs and the costs for the eventual modification of the off-gas treatment line can be counterbalanced by the fact that a significant amount of coal is saved and the delivery of combustible waste to the plant is regulated by a fee for their treatment.

In Romania, today the co-incineration capacity of the presented cement factory is about $600,000 \mathrm{t}_{\text {waste }} / \mathrm{y}$ [11-13], treating about $0.08 \%$ of the produced waste. The co-incinerated waste were the ones presented in table 1 together with the residues obtained from the treatment of these fractions and not SRF because, at the moment in Romania, a bio-drying plant or other "waste to SRF" plants do not exist but some of them are under discussion.

\section{Global and local balances}

One of the most important parameters regarding the global environmental balance is the $\mathrm{CO}_{2}$ emission factor referred to a unit of energy. It is clear that the $\mathrm{CO}_{2}$ measurable in the bio-drying air is the biogenic one $[5,16]$ but the operation of a bio-drier needs electricity, with an indirect generation of $\mathrm{CO}_{2}$. Additionally a correct balance must take into account both the $\mathrm{CO}_{2}$ from SRF co-combustion and the $\mathrm{CO}_{2}$ from SRF production. In this respect, only a part of $\mathrm{CO}_{2}$ from SRF combustion comes from not renewable sources, as RMSW and so SRF are partially biomass.

In table 2, the $\mathrm{CO}_{2}$ emission from different landfilled and combusted fractions are reported demonstrating that combustion is an interesting pathway from the environmental point of view, referring to greenhouse gases [31].

Similar advantages can be expected for SRF combustion. A case that can be taken into account is the one related to $\mathrm{CO}_{2}$ emitted using $1 \mathrm{GJ}$ coming from coal or pet-coke or fuel oil or lignite used in industrial plants compared to one $1 \mathrm{GJ}$ from SRF. The $\mathrm{CO}_{2}$ emission factors for the selected conventional fuels can be

Table 2: $\mathrm{CO}_{2}$ emission factors comparison $\left[\mathrm{CO}_{2} \mathrm{eq} / \mathrm{t}\right]$.

\begin{tabular}{|l|c|c|}
\hline Fractions & Landfilling & Incineration \\
\hline Paper and cardboard & 2.20 & 1.3 \\
\hline Plastic & 3.1 & 1.5 \\
\hline Textiles & 18 & 2 \\
\hline Green waste & 0.2 & -0.12 \\
\hline Food waste & 4.5 & 4.2 \\
\hline
\end{tabular}


taken from the literature [32]. The $\mathrm{CO}_{2}$ emission factor for SRF can be assessed taking into account the plastics content in the present and future Romanian waste $\left(\mathrm{CO}_{2}\right.$ from biodegradable fractions combustion is not taken into account). Moreover the production of SRF is related to electricity consumption depending on the characteristics of MSW (pre-treatment, bio-drying process, post-treatment) $[5,16]$. The $\mathrm{CO}_{2}$ emissions related to the used electrical energy can be referred to a Romanian thermal power plant. Starting from those hypotheses, in fig. 4, a comparison of emission factors is presented [1].

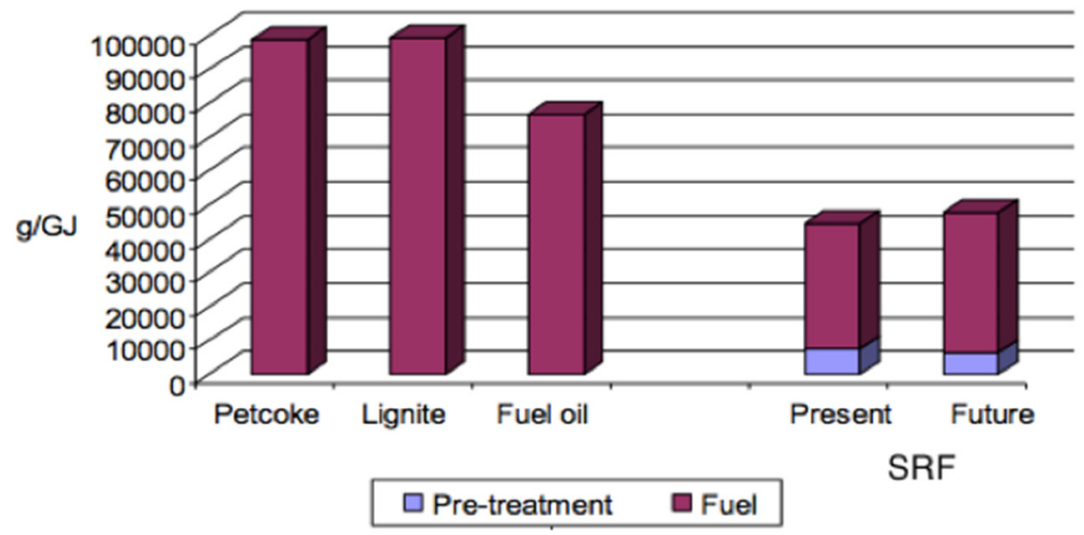

Figure 4: Comparison between $\mathrm{CO}_{2}$ emission factors.

The fuel substitution has another advantage: if SRF is not produced, it could be supposed that RMSW will be sent to a sanitary landfilling. Romania can postpone RMSW pre-treatment before landfilling until 2017 [20]. The biogas that will be generated gives a significant $\mathrm{CO}_{2}$ emission factor because of fugitive emissions. Indeed only a part of biogas can be collected, about $50 \%$. The emitted biogas has a $\mathrm{CH}_{4}$ content of about $60 \%$. In terms of greenhouse gas equivalence it must be taken into account that methane is 21 times more impacting than $\mathrm{CO}_{2}$ [32]. As a consequence, an emission factor from MSW landfilling can be assessed (always expressed as $\mathrm{g}_{\mathrm{CO} 2} / \mathrm{GJ}$ of energy in the fuel/waste) that can reach the same order of magnitude as the ones of conventional fuels. If SRF is produced, this contribution on the global balance is set to zero $[5,16]$.

Concerning local balances, a question could be related to the expected variation of emissions for instance of heavy metals. An answer could be related to the content of heavy metals in SRF compared to the one of conventional industrial fuel. In this respect, data on heavy metals in German SRF and coal demonstrate that for some heavy metals the environmental balance could be even better using SRF [1].

Concerning the co-generation plants for steam and electricity production in industrial sites for internal uses, a problem to be faced with is the compatibility of SRF with the existing burner: for instance SRF cannot substitute a liquid fuel in a system designed only for that. As a consequence the strategy based on SRF use 
should be clear from now in Romania as a number of new industrial plants are under design thanks to the attraction of foreign investments.

Another aspect regards the role of the agencies for the environmental control in Romania in order to guarantee that local impact is adequately low. A network already exists. The Romanian agencies already manage a few monitoring stations. The problem is that the conventional approach of air quality monitoring is not oriented to find specific criticalities. Thus, when an authorization to co-combustion is given, a detailed study on the local effects should be promoted. In this respect, particular attention should be given also to the role of waste transport from the environmental point of view: long distance transport of SRF could give unreasonable environmental balances [33].

\section{Conclusions}

Some considerations can be generated from the present paper:

- the present Romanian RMSW is suitable for an efficient bio-drying aimed to SRF generation;

- SRF can be an interesting substitute of conventional fuels in the industry;

- global environmental balances can be interesting thanks to the partial presence of biomass in SRF;

- SRF can be an alternative to the present use of landfilling;

- an adequate local impact can be guaranteed supporting a correct development of the activities in the local environment agencies.

What must be taken into account is that in a Romanian scenario it could be more favorable to adopt a strategy based on a decentralization of the energy exploitation of RMSW (based on SRF) as it could lower the capital costs compared to the construction of RSW incinerators.

The LHV of the Romanian the fuel obtainable from waste is more or less in line with the ones from the other EU countries where the SC has not yet very high efficiencies. Thanks to this, it is clear that the solutions applied in the other EU countries for the waste valorisation as energy sources can be applied also in Romania. However, Romania has to stimulate the use of renewable energy sources, including waste, as a part of the energy and environmental policies, promoting the use of SRF as alternative fuel through.

\section{References}

[1] Rada, E.C., Ragazzi, M. \& Apostol, T., Role of refuse derived fuel in the Romanian industrial sector after the entrance in EU. WIT Transactions on Ecology and the Environment, 109, pp. 89-96, 2008.

[2] Rada, E.C., Ragazzi, M., Panaitescu, V. \& Apostol, T., Municipal solid waste pre-treatment: A comparison between two dewatering options. WIT Transactions on Ecology and the Environment, 102, pp. 943-949, 2007. 
[3] Rada, E.C., Ragazzi, M., Panaitescu, V. \& Apostol, T., Experimental characterization of municipal solid waste bio-drying. WIT Transactions on Ecology and the Environment, 92, pp. 295-302, 2006.

[4] Velis, C.A., Longhurst, P.J., Drew, G.H., Smith, R. \& Pollard, S.J.T., Biodrying for mechanical-biological treatment of wastes: A review of process science and engineering. Bioresource Technology, 100(11), pp. 2747-2761, 2009.

[5] Rada, E.C., Ragazzi, M. \& Badea, A., MSW bio-drying: design criteria from a 10 years research. Scientific Bulletin, series D, 74(3), pp. 209-216, 2012.

[6] Velis, C.A., Longhurst, P.J., Drew, G.H., Smith, R. \& Pollard, S.J.T., Production and quality assurance of solid recovered fuels using mechanicalbiological treatment (MBT) of waste: A comprehensive assessment. Critical Reviews in Environmental Science and Technology, 40(12), pp. 979-1105, 2010.

[7] Ragazzi, M. \& Rada, E.C., RDF/SRF evolution and MSW bio-drying. WIT Transactions on Ecology and the Environment, 163, pp. 199-208, 2012.

[8] Rada, E.C. \& Andreottola, G., RDF/SRF: Which perspective for its future in the EU. Waste Management, 32(6), pp. 1059-1060, 2012.

[9] Ionescu, G., Rada, E.C., Ragazzi, M., Marculescu, C., Badea, A. \& Apostol, T., Integrated municipal solid waste scenario model using advanced pretreatment and waste to energy processes. Energy Conversion and Management, 76, pp. 1083-1092, 2013.

[10] Samolada, M.C. \& Zabaniotou, A.A, Energetic valorization of SRF in dedicated plants and cement kilns and guidelines for application in Greece and Cyprus. Resources Conservation and Recycling, 83, pp. 34-43, 2014.

[11] http://www.heidelbergcement.ro/studii-de-caz/protectia-mediului/cumreducem-poluarea-folosind-combustibili-alternativi.html

[12] http://www.holcim.ro/dezvoltare-durabila/avantajele-co-procesariideseurilor.html

[13] http://www.lafarge.ro/wps/portal/ro/2_2_2_1Expertiza_Lafarge in utilizarea_deseurilor

[14] Ghinea, C., Petraru, M., Bressers, H.T. \& Gavrilescu M., Environmental evaluation of waste management scenarios - Significance of the boundaries. Journal of Environmental Engineering and Landscape Management, 20(1), pp. 76-85, 2012.

[15] Iacoboae, C., Lua, O. \& Petrescu, F., An analysis of Romania's municipal waste within the European context. Theoretical and Empirical Researches in Urban Management, 8(4), pp. 73-84, 2013.

[16] Rada, E.C., Franzinelli, A., Taiss, M., Ragazzi, M., Panaitescu, V. \& Apostol, T., Lower heating value dynamics during municipal solid waste bio-drying. Environmental Technology, 28(4), pp. 463-469, 2007.

[17] Rada, E.C., Ragazzi, M. \& Panaitescu, V., MSW bio-drying: An alternative way for energy recovery optimization and landfilling minimization. Scientific Bulletin, series D, 71(4), pp. 113-120, 2009. 
[18] Negoi, R.M., Ragazzi, M., Aposto, T., Rada, E.C. \& Marculescu, C., Biodrying of Romanian municipal solid waste: An analysis of its viability. Scientific Bulletin, series C, 71(4), pp. 193-240, 2009.

[19] Rada, E.C., Venturi, M., Ragazzi, M., Apostol, T., Stan, C. \& Marculescu, M., Bio-drying role in changeable scenarios of Romanian MSW management. Waste and Biomass Valorization, 1(2), pp. 271-279, 2010.

[20] Cioranu, S.I. \& Badea, A., Different strategies for MSW management in two Romanian cities: Selective collection versus bio-drying. Scientific Bulletin, series D, 75(3), pp. 151-158, 2013.

[21] www.anpm.ro/Mediu/deseuri-7

[22] Rada, E.C., Ragazzi, M., Panaitescu, V. \& Apostol, T Energy from waste: the role of bio-drying. Scientific Bulletin, series C, 67(2), pp. 69-176, 2005.

[23] Ragazzi, M. \& Rada, E.C., Effects of recent strategies of selective collection on the design of municipal solid waste treatment plants in Italy. WIT Transactions on Ecology and the Environment 109, pp. 613-620, 2008.

[24] Rada, E.C., Effects of MSW selective collection on waste-to-energy strategies. WIT Transactions on Ecology and the Environment, 176, pp. 215-223, 2013.

[25] Consonni, S., Giugliano, M., Massarytto, A., Ragazzi, M. \& Saccani, C., Material and energy recovery in integrated waste management systems: Project overview and main results. Waste Management, 31(9-10), pp. 20572065, 2011.

[26] Rada, E.C. \& Ragazzi, M., Selective collection as a pretreatment for indirect solid recovered fuel generation. Waste Management, 34(2), pp. 291-297, 2014.

[27] Genon, G. \& Brizio, E., Perspectives and limits for cement kilns as a destination for RDF. Waste Management, 28(11), pp. 2375-2385, 2008.

[28] Kara, M., Gunay, E., Tabak, Y., Durgut, U., Yildiz, S. \& Enc, V., Development of refuse derived fuel for cement factories in Turkey. Combustion Science and Technology, 183(3), pp. 203-219, 2011.

[29] Kara, M., Environmental and economic advantages associated with the use of RDF in cement kilns. Resources Conservation and Recycling, 68, pp. 21-28, 2012.

[30] Rada, E.C., Ragazzi, M., Brini, M., Marmo, L., Zambelli, P., Chelodi, M. \& Ciolli, M., Perspectives of low-cost sensors adoption for air quality monitoring. Scientific Bulletin, series D, 74(2), pp. 241-250, 2012.

[31] https://www.foeeurope.org/sites/default/files/publications/FoEE SERI me asuring europes resource use 0609.pdf

[32] IPCC/OECD/IEA Revised 1996 IPCC Guidelines for National Greenhouse Gas Inventories. 1997.

[33] Ciuta, S., Schiavon, M., Chistè, A., Ragazzi, M., Rada, E.C., Tubino, M., Badea, A. \& Apostol, T., Role of feedstock transport in the balance of primary PM emissions in two case-studies: RMSW incineration vs. sintering plant. Scientific Bulletin, series D, 74(1), pp. 211-218, 2012. 